„Przekłady Literatur Słowiańskich”. T. 9, cz. 3 ISSN 2353-9763 (wersja elektroniczna)

DOI 10.31261/PLS.2019.09.03.17

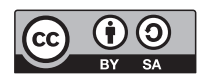

\title{
Bibliografia przekładów literatury słowackiej w Polsce w 2017 roku
}

\section{The Bibliography of Translations of Slovak Literature in Poland in 2017}

\author{
Marta Buczek \\ (iD https://orcid.org/0000-0001-9623-2460 \\ UNIVERSITY OF SILESIA IN KATOWICE \\ marta.buczek@us.edu.pl
}

Data zgłoszenia: 16.02.2019 r. ｜Ｄata akceptacji: 15.03.2019 r. 


\section{Publikacje książkowe}

1. Púček Ján: Uchom ihly (pletky) / Przez ucho igielne (sploty).

Tłum. Weronika G o g o la. Wrocław, Książkowe Klimaty, 2017, 336 s.

[proza].

2. Vadas Marek: Liečitel' / Uzdrowiciel.

Tłum. Małgorzata D a m b e k. Wrocław, Książkowe Klimaty, 2017, 156 s. [proza].

\section{Publikacje w czasopismach}

1. Abilion. Prezentacje, 5 lipca 2017, źródło internetowe:

https://abilion.eu/prezentacje/wiersze-z-tomiku-poetyckiego-radovana -brenkusa-snienie-z-bestia.html.

\section{Brenkus Radovan}

[Ze zbioru Snívanie s netvorom, 2015 / Śnienie z bestia, 2016]

Oko blúzniace spod ladovca / Oko majaczace spod lodowca

Vídat známe tváre v cudzích / Widać znane twarze obcych

$V$ predposlednom obraze / W przedostatnim obrazie

Z jamy zarastenej machom / Z jamy zarośniętej mchem

Z rozkoše sme vyhnali otrávený sen I

$Z$ rozkoszy wygnaliśmy zatrute śnienie.

Tłum. Marta Pelinko [poezja].

2. „Dialog” 2017, nr 7-8 (728-729).

\section{Klimaček Viliam}

Divná doba, divná láska, divné životy / Dziwne czasy, dziwna miłość, dziwne żywoty.

Tłum. Andrzej S. J a g o d z i ń s k i [dramat].

3. „Literatura na Świecie” 2017, nr 7-8 (552-553).

\section{Balko Peter}

Vtedy $v$ Lošonci / Wtedy w Loszoncu.

Tłum. Miłosz Wa li gó r s ki, s. 149-193 [proza].

\section{Dušek Dušan}

[Ze zbioru Kufor na sny, 2012 / Walizka na marzenia]

Pes / Pies, s. 107-108

Poklad $v$ nohaviciach / Skarb w spodniach, s. 102-104

Sandále / Sandały, s. 104-107

Vianoce / Boże Narodzenie, s. 101-102

Výhoda / Pożytek, s. 108-109.

Tłum. Krzysztof Re j m e r [proza]. 
Topografia / Topografia, s. 130-132.

Tłum. Andrzej S. J a g o d z i ń s k i [proza].

Zberatel' / Kolekcjoner, s. 109-112.

Tłum. Krzysztof R e j m e r [proza].

[Ze zbioru Náprstok, 2005 / Naparstek]

Piesok / Piasek, s. 113-129.

Tłum. Krzysztof R e j m e r [proza].

\section{Johanides Ján}

Inzeráty pre večnost' / Ogłoszenie dla wieczności.

Tłum. Izabela Z a ją c, s. 63-95 [proza].

\section{Kovalyk Uršula}

Krasnojazdkyňa / Woltyżerka.

Tłum. Krzysztof R e j m e r, s. 199-228 [proza].

4. „Poezja Dzisiaj” 2017, nr 121-122.

\section{Milčák Peter}

Miejsce $e^{* * *}$

Siła ${ }^{* * *}$, s. 36 [poezja].

5. „Poezja Dzisiaj” 2017, nr 124-125.

\section{Milčák Peter}

Viktor, Karol a namorníček / Wiktor, Karol i marynarzyk** [poezja].

6. „Wers” [magazyn literacki] 2017, nr 4 (112).

\section{Brenkus Radovan}

Gdy się wie dlaczego musi być niebo*

Tłum. Marta Pelinko, s. 14 [poezja].

7. „Wers” [magazyn literacki] 2017, nr 8 (116).

\section{Brenkus Radovan}

Śnienie $z$ bestia [fragmenty poematu]

${ }_{* * *}($ Gdy się wie, dlaczego musi być niebo...)*

***(Zaraz gdy mu do oczu wciśnie się przepaść... $)^{\star}$

Tłum. Marta Pelinko, s. 13 [poezja].

MARTA BUCZEK | dr, literaturoznawca, słowacystka, starszy wykładowca w Zakładzie Teorii Literatury i Translacji Instytutu Filologii Słowiańskiej Uniwersytetu Śląskiego w Katowicach. Prowadzi badania z zakresu translacji w obrębie literatur zachodniosłowiańskich w perspektywie teoretycznej, historycznoliterackiej i historycznokulturowej. Zajmuje się przekładem i recepcją literatury słowackiej w Polsce ze szczególnym uwzględnieniem literatury XX wieku oraz literatury najnowszej. Jest autorką książki pt.: O polskich przekładach prozy Vincenta Šikuli (2010) i ponad dwudziestu artykułów naukowych koncentrujących się wokół badań nad przekładem, recepcji literatury polskiej w Słowacji i słowackiej 
w Polsce, kulturowych uwarunkowań przekładu, specyfiki przekładu w granicach języków bliskopokrewnych, roli przekładu w badaniach komparatystycznych. 